CURRENT RESEARCH JOURNAL OF PHILOLOGICAL SCIENCES

(ISSN -2767-3758)

VOLUME 03 ISSUE 01 Pages: 111-114

SJIF IMPACT FACTOR (2021: 5 . 823)

OCLC - 1242423883 METADATA IF - 6.925

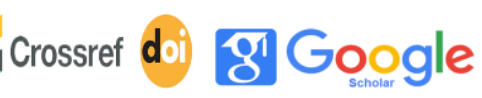

\%

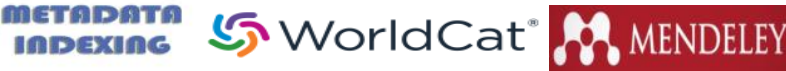

Publisher: Master Journals

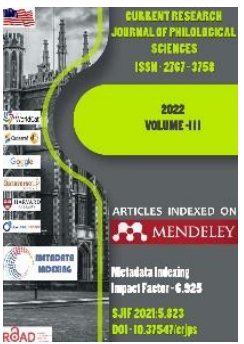

Journal Website: https://masterjournals. com/index.php/crips

Copyright: Original content from this work may be used under the terms of the creative commons attributes 4.0 licence.
Research Article

\section{WAYS OF CREATIVE THINKING OF PRIMARY SCHOOL STUDENTS IN TEACHINGS FOREIGN LANGUAGES}

\author{
Submission Date: January 11, 2022, Accepted Date: January 21, 2022, \\ Published Date: January 31, 2022 \\ Crossref doi: https://doi.org/10.37547/philological-crjps-03-01-19
}

\section{Guzal Sharipova}

Master Student, Samarkand State Institute Of Foreign Languages, Uzbekistan

\title{
ABSTRACT
}

Creativity is considered as the most important and relatively independent factor of giftedness, whichrarely reflected in intelligence tests and academicachievements. On the contrary, creativity is not definedso much critical attitude to the new from the point of viewexperience, how much receptivity to new ideas.

\section{KEYWORDS}

Creativity, intelligence, primary school, student, language.

\section{INTRODUCTION}

An integrated approach to the education of a creative personality covers a wide range of issues related toto problems and moral education. Inseparablethe unity of the ideological and ideological, spiritual and artistic is an indispensable condition for the personalitya growing person, the versatility and harmony of its development.
Foreign language as a general education curriculumthe subject can and should contribute to the process of developing the creative abilities of students. With a huge upbringing, educational and developmental potential of students, a foreign language canto realize it only in the course of the implementation of the practical goal of training, that is, only ifthe student in the process of foreign 


\section{CURRENT RESEARCH JOURNAL OF PHILOLOGICAL SCIENCES}

(ISSN -2767-3758)

VOLUME 03 ISSUE 01 Pages: 111-114

SJIF IMPACT FACTOR (2021: 5. 823)

OCLC - 1242423883 METADATA IF - 6.925

language communicative and cognitive activity (listening, speaking, reading, using writing) will expand his horizons, develop his thinking, memory, feelings and emotions. BeforeFirst of all, a foreign language as a subject is an additional "window" to the world, it is a means to replenish knowledge in various areas of life, science, art,what is essential for general education, it is a tool that helps to carry out activities in differentareas of work and social life.In the classroomin a foreign language, students deepen and expand many of the knowledge and ideas they have receivedother academic subjects: social science, literature,music, history, geography, fine arts, etc. Determining the possible development of creativity(general creative abilities) in younger students, it is necessary to rely on the point of view formed in the scientific literature that its sensitive periodruns for 8-9 years. It is at this age that personality traits such asa sense of novelty, criticality, focus on creativity, the ability to transform. At this time, imitation of an adult (parents, teacher) as a modelis a determining factor in the formation of creativity.

\section{THE MAIN FINDINGS AND RESULTS}

A foreign language lesson has its own specifics, soas, unlike other subjects, as the mainlearning objectives put forward the formation of communicative competence of students.

At present, the global goal of mastering a foreign language is considered to be familiarization with a different cultureand participation in the dialogue of cultures. This goal is achieved throughformation of the ability to intercultural communication. It is teaching organized on the basis oftasks of a communicative nature, as well as trainingforeign language communication, using all the tasks and techniques necessary for this, is a distinctive feature of a foreign language lesson.

Foreign language communication is based on the theory of speech activity. Communicative teaching of a foreign language is active in nature, since verbal communication is carried out through"speech activity", which, in turn, servesto solve the problems of productive human activity in the conditions of "social interaction" of communicating people. Participants of communication try to solve real and imaginary tasks of joint activityusing a foreign language.

The activity essence of communicative-oriented teaching of a foreign language is realizedin a humanistic approach to learning. AtThis approach creates positive conditions for the active, free, creative development of the individual in activity. In general, these conditions are as follows:

- students get the opportunity to freely express their thoughts and feelings in the process of communication;

- each participant of communication remains in focus of attention of the others;

- participants in communication feel safefrom criticism, persecution for mistakes and punishment.

With a humanistic approach to learning disappearcognitive barriers characteristic of the educational process that reduce the motivation of students, encouragethem to irritability.

As mentioned earlier, a foreign languagehas great potential for developing the creative abilities of students. Influencing the personalitythe formation of creative abilities enriches emotional and practical experience, develops the psyche, 


\section{CURRENT RESEARCH JOURNAL OF PHILOLOGICAL SCIENCES}

(ISSN -2767-3758)

VOLUME 03 ISSUE 01 Pages: 111-114

SJIF IMPACT FACTOR (2021: 5. 823)

OCLC - 1242423883 METADATA IF - 6.925

forms intellectual potential, promoteseducation of aesthetic and mental abilities,leads to the accumulation of professional skills and abilities, development of the natural inclinations of children, their moral qualities. It sets up for further, active, creatively conscious amateur activity of schoolchildren, whichmeets their spiritual needs, satisfies themthe desire for self-realization, and the manifestation of personalqualities. All this is an effective tool for the integrated development of personality, identifying the formationher creative potential.

One of the means that promote creativityThe development of the student's personality is the use of non-traditional forms of a foreign language lesson.Non-traditional forms of an English lesson are implemented, as a rule, after studying anytopics or several topics, acting as a learningcontrol. Such lessons take place in an unusual, non-traditional setting. Such a change in the usual environment is advisable, since it creates an atmosphereholiday when summing up the results of the work done,removes the mental barrier that arises in traditional conditions due to the fear of making a mistake. Non-traditional forms of a foreign language lesson are carried out with the obligatory participation of all students in the groupor class, and are also implemented with the indispensable use of auditory and visual visual aids. On thesuch lessons manage to achieve a variety of goals of a methodological, pedagogical and psychological nature, which can be summarized as follows:

- control of knowledge, skills and abilities is carried outstudents on a particular topic;

- provides a businesslike, working atmosphere, a serious attitude of students to the lesson;

- there is a minimum participation in the lessonteachers.
In our time, when more and more are developingconnections between different countries and peoples, acquaintancewith Russian national culture becomes a necessary element of the process of learning a foreign language.The student should be able to conduct a city tour, tell foreign guests about the identity of the uzbekculture, etc. The principle of the dialogue of cultures presupposesthe use of cultural material about the nativecountry, which allows you to develop a culture of representing your native country, as well as to form ideas about the culture of the countries of the language being studied.

When planning lessons, the teacher should think not only aboutso that students memorize new words, one or anotherstructure, but also sought to create all the possibilities fordevelopment of the individuality of each child. Importancethe development of the creativity of a younger student, his abilities in solving any educational problem to show initiative, invention, independence for everyone isnow obvious. Correlating the process of creativity and learning, obviously, we need to talk about the creation of suchconditions conducive to the emergence andthe development of all trainees' qualities and inclinations, usually identified as characteristic features of a creative personality. School performance is determined byto what extent the educational process ensures the development of the creative abilities of students, prepares them for life in society.

\section{CONCLUSION}

Thus, we can conclude that every child has creative abilities. These are individual psychological characteristics that distinguish one person from another. How developed they aredepends on the creative potential of our society, asThe formation of a creative personality today acquires not only a 
CURRENT RESEARCH JOURNAL OF PHILOLOGICAL SCIENCES

(ISSN -2767-3758)

VOLUME 03 ISSUE 01 Pages: 111-114

SJIF IMPACT FACTOR (2021: 5. 823)

OCLC - 1242423883 METADATA IF - 6.925

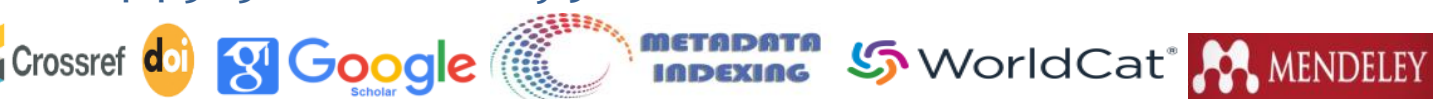

Publisher: Master Journals

theoretical meaning, but also a practical meaning.Knowledge of teachers, what is meant by creativeabilities of students, will expand the boundaries of their manifestation in children.

\section{REFERENCES}

1. Fried - Booth Diana L. Project work. OUP, 2016, p. 8.

2. Hutchinson T. Introduction to Project Work. OUP, 2011, p. 21

3. Zalesova N.V., Bashlykova A.V. [Creative tasks as a means of developing students' cognitive interest]. Bulletin of the Shadrinsk State Pedagogical Institute, 2019, no. 2, pp. 150-155.

4. www.ziyonet.uz 